\title{
Editorial
}

\section{Welcome to the New Avatar of South Asian Journal of Cancer-9th Year and Beyond}

\author{
Sachin Hingmire ${ }^{1}$, Purvish M. Parikh ${ }^{1}$ \\ ${ }^{1}$ Consultant Medical Oncologist, Deenanath Mangeshkar Hospital \\ and Reasearch Centre, Pune
}

South Asian J Cancer:2020;9:69

South Asian Journal of Cancer(SAJC) is now in its 9th successful year. As we move to greater heights, we also move to a new publisher-Thieme Medical and Scientific Publishers Private Limited. This move is specifically selected to secure the future of SAJC with a publisher that puts quality and value above all else. While our main Web site remains unchanged (www.sajc.org), manuscripts can now be submitted at www.manuscriptmanager.net/sajc and published articles accessed at www.thieme.com/sajc.

What we have achieved so far is to make the journal acceptable across the globe as well as its quality officially recognized in India and other SAARC countries. It is the official journal of SAARC Federation of Oncologists (SFO), Integrated Academic Society of Clinical Oncology (IASCO), Indian Cooperative Oncology Network (ICON), and Oncology Gold Standard (OGS). More than 600 articles are submitted to us annually and we are able to select the most appropriate high quality $25 \%$ among them for publication.

Our huge network of reviewers is to be appreciated for their diligent work in ensuring that the readers and subscribers get only the best quality of manuscripts. We continue to provide open access to promote science for the benefit of humanity at large.
We have now revamped the editorial team and welcome the new members. We also thank the previous team profusely-including editorial board members, diligent reviewers, authors, and all those who submitted their manuscripts to SAJC. Special thanks to the past editors of SAJCDr. Shweta Bansal and Dr. Vanita Noronha. They laid the foundation on which the journal has continued to prosper.

Where do we see the future of oncology with respect to education in general and areas of priority for SAJC publication in particular? Clearly, our intention is to be one step ahead, for which we anticipate the future. No doubt high quality original research work will be the backbone for SAJC. Every field in oncology and related subjects will have innovations of importance, which are most welcome. We believe our readers will benefit most by addition of some novel sections-a few of them shall include cardio-oncology, medico legal issues, innovative diagnostic technology, novel therapeutics, and practical recommendations.

We invite you to join hands in the SAJC journey and find a speedy and fair platform to publish your work at a fast pace. We will publish accepted articles ahead of print and make them available quickly to the global health care community.
Address for correspondence: Dr Sachin Hingmire, Consultant Medical Oncologist, Deenanath Mangeshkar Hospital and Reasearch Centre, Pune (e-mail: sshingmire@yahoo.com).
DOI https://doi.org/ $10.1055 / \mathrm{s}-0040-1721535$ ISSN 2278-330X.
(C) 2020. Medlntel Services Pvt Ltd.

This is an open access article published by Thieme under the terms of the Creative Commons Attribution-NonDerivative-NonCommercial-License, permitting copying and reproduction so long as the original work is given appropriate credit. Contents may not be used for commercial purposes, or adapted, remixed, transformed or built upon. (https://creativecommons.org/licenses/by-nc-nd/4.0/)

Thieme Medical and Scientific Publishers Pvt. Ltd., A-12, 2nd Floor, Sector 2, Noida-201301 UP, India 